\title{
The Study On The Income And Purchasing Power Of North Sumatera Province
}

\author{
Delima Lubis \\ Universitas Muhammadiyah Tapanuli Selatan
}

\begin{abstract}
North Sumatra Province has been the central node of Indonesian economy growth in Sumatra of Indonesia. The development of this province affects the regional economy. This study aimed at finding the effect of income levels on the purchasing power of the people of North Sumatra. To find the economic and welfare of population in this province, an associative research approach was conducted. It sought the level of income per capita correlation to the purchasing power of North Sumatra Province. The data from Central Bureau of Statistic (BPS, 2016) in which economic transactions of 2007 2015 was realised. The data analyze technique was a simple linear regression equation. After the calculation and analysis, the results showed that the level of income has a positive and significant impact on people's purchasing power in North Sumatra. It concluded the higher the income level of the North Sumatra population made the purchasing power increasing. So purchasing power was better if the income had beeen sufficient to meet the daily needs.
\end{abstract}

Keywords: Income level, purchasing power, daily needs

\section{INTRODUCTION}

North Sumatra is a Province in Indonesia which has many ethnic groups and economic power. Its capital is Medan Municipal after the Dutch colonial in 1890 grew to be industrial location where many new migrants (Mantondang, 2016) from India, China, and Middle East opened the modern trade and busineness. Immirants were not directly from South China, but from Penang Malaysia (Matondang, 2012). This study focus on the North Sumatra economy power not only showed the income but the potent purchase power. It is noted that the purchasing power is strongly influenced by the income of society (Sukirno, 2005). Purchasing power of the nation is determined by its income and its monetary policy (Arize et. al, 2018:102). For most goods, an increase in income leads to an increase in demand. If the elasticity value of income change, so the demand will change of the elasticity level. It is a positive indicator then the goods are called normal goods.

Numerous factors can affect the price elasticity of demand, including closeness of substitute products, importance of the good in terms of expenditure, time for adjustment, product durability, and range of uses(Fibich, Gavious, and Lowengart, 2005:66).Elasticity is a measure of the degree of sensitivity changes in the amount of demand for goods on price changes. In addition, if there is an item that has decreased in the quantity purchased if the income increases means the elasticity is negative and the goods are called inferior goods. This elasticity is called income elasticity.

The increase in income levels of the poor stimulated the overall increase in product demand, which in turn creates improved conditions of economic growth(Todaro, 2006). Public purchasing power which is one of the benchmarks of community welfare assessed from the Human Development Index, especially in North Sumatera area. It had been seen from the per 
capita population expenditure rate from year to year. The expenditure per capita of North Sumatera population from 2007 to 2015 was seen in Table 1.

Table 1: Expenditure Per Capita Rate in North Sumatra Province 2007 - 2015

\begin{tabular}{|c|c|c|c|c|c|}
\hline \multirow{2}{*}{ No } & \multirow{2}{*}{ Year } & \multicolumn{3}{|c|}{$\begin{array}{c}\text { Expenditure Per Capita } \\
\text { (IDR/month) }\end{array}$} \\
\cline { 3 - 5 } & & Food & Non Food & Total & (IDR/month) \\
\hline 1 & 2007 & 207,606 & 275,060 & 482,666 & - \\
2 & 2008 & 227,521 & 250,148 & 477,669 & $-4,997$ \\
3 & 2009 & 257,661 & 274,781 & 532,442 & 54,773 \\
4 & 2010 & 288,594 & 328,487 & 617,081 & 84,639 \\
5 & 2011 & 324,392 & 312,932 & 637,324 & 20,243 \\
6 & 2012 & 349,032 & 316,579 & 665,611 & 28,287 \\
7 & 2013 & 363,478 & 380,777 & 744,255 & 78,644 \\
8 & 2014 & 416,319 & 381,027 & 797,346 & 53,091 \\
9 & 2015 & 416,073 & 453,609 & 869,682 & 72,336 \\
\hline
\end{tabular}

Source: BPS (2016)

The table above shows that the purchasing power of the community continued to increase from 2008 to 2009 even with a fluctuating percentage increase. The highest increase was in 2010 which reached IDR 84.639, - / month, while the lowest increase occurred in 2011 with an increase of IDR 20.243, - / month.

The income level per capita of North Sumaterain Year 2007 - 2015; It can be seen in Table 2.

Table 2: IncomePer Capita Rate in North Sumatra Province 2007 - 2015

\begin{tabular}{|c|c|c|c|}
\hline No & Year & $\begin{array}{c}\text { Income Per Capita } \\
\text { (IDR/month) }\end{array}$ & $\begin{array}{c}\text { Changes } \\
\text { (IDR/month) }\end{array}$ \\
\hline 1 & 2007 & $680,366.40$ & - \\
2 & 2008 & $690,710.70$ & $10,344.30$ \\
3 & 2009 & $720,699.60$ & $29,988.90$ \\
4 & 2010 & $762,380.10$ & $41,680.50$ \\
5 & 2011 & $801,337.20$ & $38,957.10$ \\
6 & 2012 & $841,091.40$ & $39,754.20$ \\
7 & 2013 & $880,291.20$ & $39,199.80$ \\
8 & 2014 & $914,477.70$ & $34,186.50$ \\
9 & 2015 & $931,020.60$ & $16,542.90$ \\
\hline
\end{tabular}

Source : BPS (2016)

Table 2 shows that the level of income per capita of the community in North Sumatra Province continues to increase from 2007 to 2015. The biggest increase occurred in 2010 which amounted to IDR 41,680.50 / month and the smallest occurred in 2008 which amounted to IDR $10,344.30$ / month.

It should be noted that the purchasing power is closely related to the income level of the community. If the income level of society is high, it affects the ability of people's purchasing power. Community income is closely related to the work done. Unemployment will result in a lack of income that ultimately affected people's purchasing power.

Based on the above description then conducted research on the effect of income levels on the purchasing power of the people of North Sumatra. 


\section{Research Method}

This reserach applied a document analysis with an associative approach.The documents have been analyzed to identify contemporary approaches defined by strategies, programs and research reports in the context of achieving resilient sustainable development (Crnčević \& Louren, 2018:108). An associative approach in this study that aimed to find the influence or relationship between two or more variables. Thus, Wedyan \& Wedyan (2013:889) argued that one of the recent data mining techniques is associative classification (AC) which integrates two known data mining tasks, association rule mining and classification. The classification step is added in order to use the produced classifier model for the purpose of prediction. The two data mining tasks are analogues, with the exception that classification aims to forecast the class label, while association rule describes correlations among items in a transactional dataset. Furthermore, the independent variables in this study was the level of income per capita, while the dependent variable took the purchasing power of North Sumatra Province, Indonesia.

Data collection involved the documents of Statistics. The data obtained not from the primarily source, but the official ones of Central Board of Statistics (BPS, 2016). Those included the level of income and purchasing power of North Sumatra in 2007 - 2015.

The data obtained was calculated through a simple linearregression equation and its processing using statistical aid software tools SPSS version 19 for windows (Ghozali, 2005).

\section{THEORETICAL REVIEWS}

\section{Purchasing Power}

Purchase and consumption behaviors in daily life often are repetitive and performed in customary places, leading consumers to develop habits. When habits have formed, environmental cues can activate the practiced responses in the absence of conscious decision making (Ji and Wood, 2007:1).The financial or economics situation of consumers will affect their purchase power aas well because income is an important source of purchasing power (Hee \& Yen, 2018:150). Purchasing power (Average Per capita Real Adjusted Performance) is the ability of people to spend their money in the form of goods or services. The ability of purchasing power between regions varies with the highest range of 732,720 and the lowest of 360,000 . The lower value of the purchasing power of a society is closely related to the economic condition at that time which is deteriorating which means the lower the ability of the public to buy a good or service (HDI 2007 - 2008, BPS Jakarta).

Sukirno (2011) explained that there are several factors that determine the level of household expenditure either in small units or overall economy. The most important is the household income, where there is the influence of consumption expenditure if there is an increase in income. Usually the income increase is higher than the increase of consumption.Furthermore Sukirno (2011) also said that if the income does not change then the price increase causes the real income becomes less. In other words, the earning ability received to buy goods is smaller than before. So the price increase causes consumers to reduce the amount of various goods bought, including goods that experience price increases.

\section{Income Level}

Income is the sum of all money received by a person or household for a period of time (usually one year). Income consists of wages or labor receipts, income from wealth such as rent, interest and dividends and payments or receipts such as social benefits or unemployment assumptions (Samuelson and Nordhaus, 1993). Winardi (1991) stated that the income is goods or services that had been consumed during a certain period. Thus the income appears to have an influence on consumption and savings increases as well.additionally, Ferrer-i- 
Carbonell (2004:998) stated that the majority of individuals express much interest in obtaining a higher income level, indicating that this is an explicit goal for most people.

Development basically leads to two things: increased income per capita and the occurrence of changes in economic structure. In general, changes in economic structure can occur with the change of contribution rate in each sector line. An increase in the percentage contribution of a sector to total national product or income indicates that the sector is increasingly instrumental in boosting the economy. The absence of a change in the role of each sector to total national income indicates that the development does not change the economic structure (Hudiyanto, 2013).

\section{RESULTS AND DISCUSSION}

\section{Description of Community Purchasing power in North Sumatra Province 2007-2015}

The purchasing power of the people in North Sumatera province was high and fluctuated; and overall in the year of study (2007-2015) was increasing. However, in general, North Sumatrapurchasing power tended rising; it was found that the needs of people tend to be high on goods and services. The sufficient fulfilled was rising up. Thatfact was particularly considered to be particularly hard for the low-income category.

The welfare was seen from the ability of people's purchasing power level. The greater the level of people's purchasing power, the higher the welfare level found. Conversely, the lower the purchasing power, the lower the welfare level of the people came. The ability of a person's purchasing power was influenced the income and the daily needs (expenditure level). According to the Central Bureau of Statistics (2004), stated that the amount of income a person who is below IDR 600.000 then declared a person included in the category of poor.

In order to clearly illustrate the purchasing power of the people of North Sumatra province during the period of 2007 - 2015 presented in Figure 1.

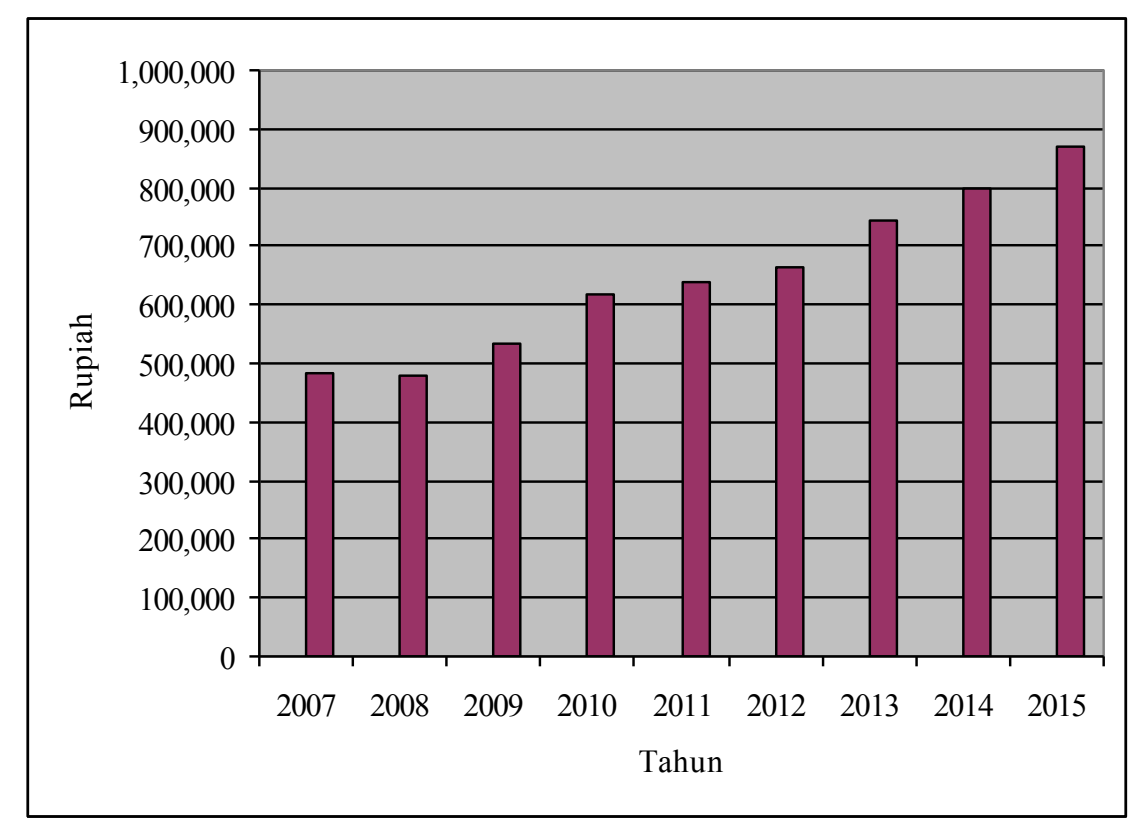

Figure 1. Community purchasing power in North Sumatra Province $2007-2015$

Based on the histogram of people's purchasing power in North Sumatra Province in 2007 2015 has increased significantly from year to year. In 2008, the purchasing power of IDR 477,699 per month and the highest purchasing powerwad in 2015 of IDR 869,682 per month. These findings show that descriptively, the growth of positive income levels has a positive impact on people's purchasing power. 
The clear picture of the development of the purchasing power of the people of North Sumatra province during the period of 2007 - 2015, shown in Figure 2 is shown as a line graph.

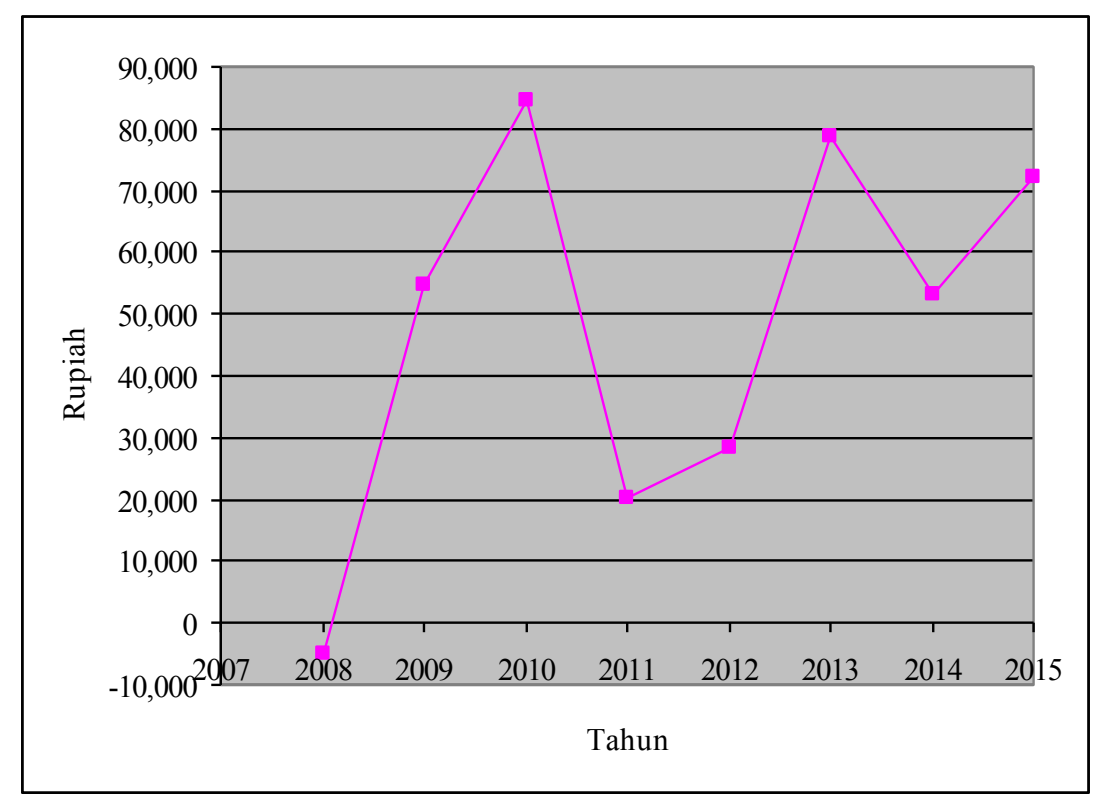

Figure 2. Growth of Community Buying Power in North Sumatra Province 2007 -2015

Based on the graph of the growth of purchasing power of the people of North Sumatra province in the figure 2 above, during the period of 2007 - 2015 from year to year people's purchasing power had a fluctuating increase and there was a period also decreased (negative growth) in 2008.

\section{Description of Income Level of North Sumatera Community}

In order to clearly illustrate the income level of the people of the province of North Sumatra during the period of 2007 - 2015 presented in Figure 3.

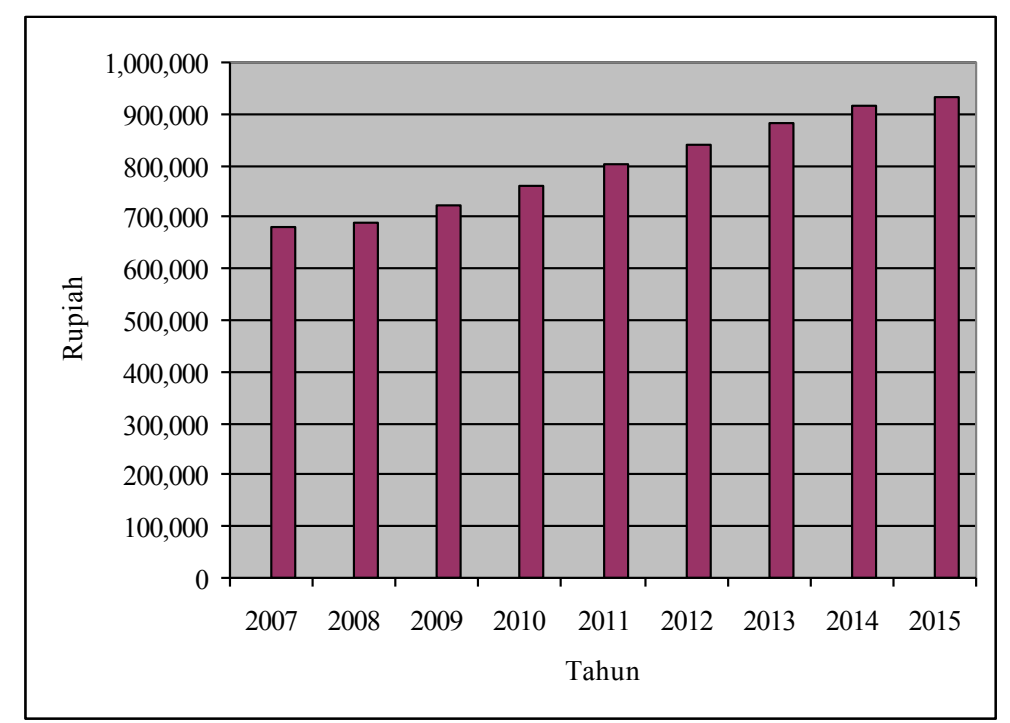

Figure 3. Community Revenue Rate in North Sumatra Province in $2007-2015$

Based on the histogram income level of the community in North Sumatra Province in 2007 2015 experienced a significant increase from year to year. In 2007, the highest income level was IDR 680,366.40 per month and the highest income level in 2015 was IDR 931,020.60 per month. 
The graphic of the development of the income level of the people of North Sumatra province during the period of 2007 - 2015, shown in Figure 4,

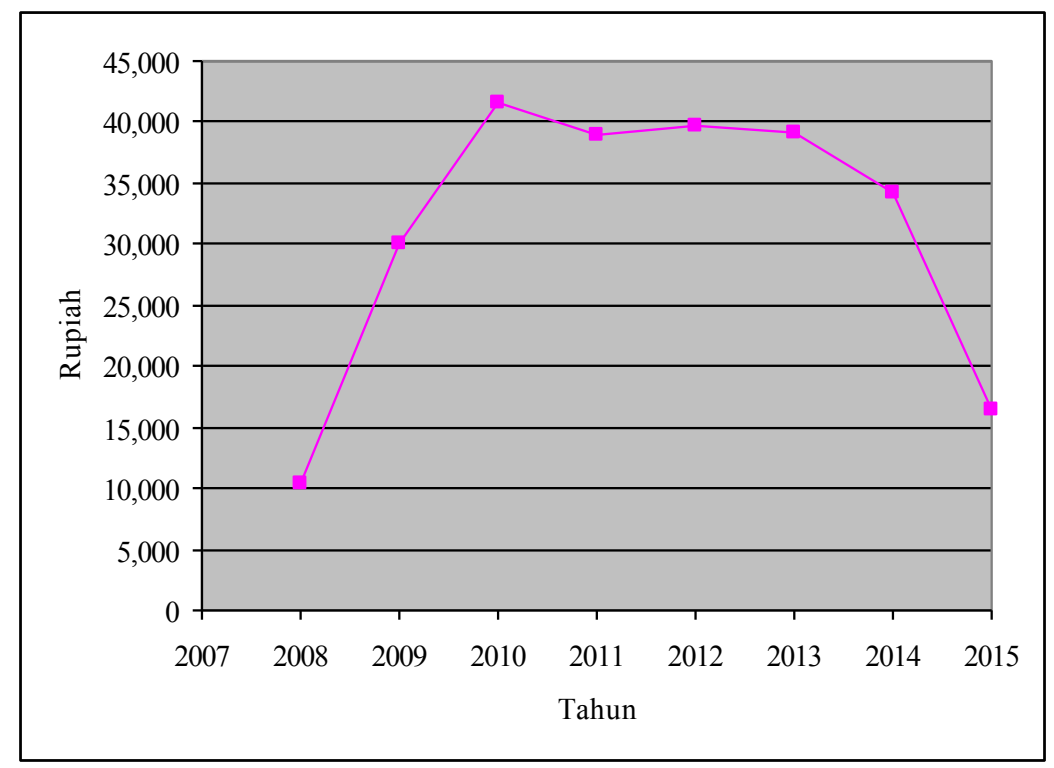

Figure 4. Growth of Revenue Rate in North Sumatera Province in 2007 -2015

Based on the graph of population income growth of North Sumatera Province in the figure above, during the period of 2007 - 2010 the growth of income level of society has increased significantly, and stagnant in year 2010 - 2013. In year 2013 until year 2017 decreased.

\section{Influence of Income Level on thePurchasing power of North SumateraProvince}

To know the influence of income level to public purchasing power was done by simple linear regression test as in Table 3.

Table 3: Simple Linear Regression Test Result

Coefficients $^{\mathrm{a}}$

\begin{tabular}{|c|c|c|c|c|c|c|}
\hline \multirow{2}{*}{\multicolumn{2}{|c|}{ Model }} & \multicolumn{2}{|c|}{ Unstandardized Coefficients } & \multirow{2}{*}{$\begin{array}{c}\text { Standardized } \\
\text { Coefficients } \\
\text { Beta }\end{array}$} & \multirow[b]{2}{*}{$i$} & \multirow[b]{2}{*}{ Sig. } \\
\hline & & $\mathrm{B}$ & Std. Error & & & \\
\hline \multirow[t]{2}{*}{1} & (Constant) & 361993.221 & 28511.110 & & 12.697 & .000 \\
\hline & Daya_beli & .681 & .043 & .986 & 15.758 & .000 \\
\hline
\end{tabular}

a. Dependent Variable: Tingkat_pendapatan

Regression equation:

$$
\mathrm{Y}=361,993.221-0.681 \mathrm{X}
$$

From Table 3 above, it can be seen that the significance value $t$ for the income level variable of 0.00 is less than 0.05 . so it concluded that there was a significant relationship between the level of income with purchasing power in North Sumatra. This means that the higher the level of people's income then made the purchasing power also increasing.

\section{CONCLUSIONS}

From the discussion of obtained data of the effect of income levels on the purchasing powerof the people of North Sumatra Province, some concluding sentences are made as followings;

1. Income level of North Sumatra Province in 2007 -2015 made a positive and significant impact on people's purchasing power. The higher the income level made an increase of 
the purchasing power. The purchasing powerdecreased was due to the income was not sufficient to meet the daily needs.

2. A decrease in growth in income levels of people in North Sumatra, especially in 2008 the period, caused by several things such as the increasing number of workers and low employment growth. The local government already made the fiscal stimulus to uplift the job vacancies which increased income in 2009.

\section{BIBLIOGRAPHY}

Arize, A. C., Kallianiotis, I. N., Malindretos, J., Panayides, A., \& Tsanacas, D. (2018). A Comparison of the Current Account and the Monetary Theories of Exchange Rate Determination. International Journal of Economics and Finance, 10(2), 102.

BPS, (2004), Indeks Pembangunan Manusia Indonesia Tahun 2007-2008, Jakarta : Badan Pusat Statistik

BPS, (2009), Indeks Pembangunan Manusia Indonesia Tahun 2001-2008, Jakarta : Badan Pusat Statistik

Crnčević, Tijana., Lovren, Violeta Orlović.(2018). Displacement and climate change: improving planning policy and increasing community resilience, International Journal of Climate Change Strategies and Management, Vol. 10 Issue: 1, pp.105-120, https://doi.org/10.1108/IJCCSM-05-2017-0103

Ferrer-i-Carbonell, A. (2004). Income and Well-being: an Empirical Analysis of the Comparison Income Effect. Journal of Public Economics. Vol.89. doi:10.1016/j.jpubeco.2004.06.003

Fibich, G., Gavious, A., Lowengart,0. (2005). The Dynamics of Price Elasticity of Demand in the Presence of Reference Price Effects. Journal of the Academy of Marketing Science, 33, (1), Doi 10.1177/0092070304267108. Academy of Marketing Science.

Ghozali, Imam, (2005). Aplikasi Analisis Multivariate dengan Program SPSS, Semarang : Badan Penerbit Universitas Diponogoro.

Hee, O. C., \& Yen, W. S. (2018). The Influence of Advertising Media towards Consumer Purchasing Behavior in the Food and Beverage Industry in Malaysia. International Journal of Human Resource Studies, 8 (2).

Hudiyanto, (2013). Ekonomi Pembangunan. Pusat Pengembangan Ekonomi Universitas Muhammadiyah Yogyakarta, Yogyakarta.

Ji, Mindy F., and Wood, Wendy. (2007). Purchase and Consumption Habits: Not Necessarily What You Intend. Journal Of Consumer Psychology, 17(4), 261-276

Matondang, Saiful Anwar, (2012). Interethnic perceptions of ethnic boundaries in Penang, Malaysia, University of Hawai'i Manoa : Honolulu USA.

Matondang, Saiful Anwar, (2016). The Revival of Chineseness as Ethnic Identity in Malaysia, Khazar Journal of Humanities and Social Sciences, 19 (4).

Samuelson P. A, dan William D. Nordhaus, (1993). Micro Economics, Translated by Drs. Haris Munandar DKK, Edisi ke-14. Jakarta : Erlangga.

Sukirno, Sadono. (2005). Makroekonomi Teori Pengantar, 3rd Ed. Penerbit Raja GrafindoPersada, Jakarta.

Sukirno, Sadono, (2011). Makroekonomi, Teori Pengantar, 3rd Ed, Jakarta : Raja Grapindo Persada.

Todaro, Michael P, (2006). Pembangunan Ekonomi di Dunia Ketiga, 7th Ed, Jakarta :Erlangga.

Wedyan, S., \&Wedyan, F. (2013). An Associative Classification Data Mining Approach for Detecting Phishing Websites. Journal of Emerging Trends in Computing and Information Sciences, 4(12).

Winardi.(1991). Marketing dan Perilaku Konsumen. Bandung :MandarMaju. 